\title{
J
}

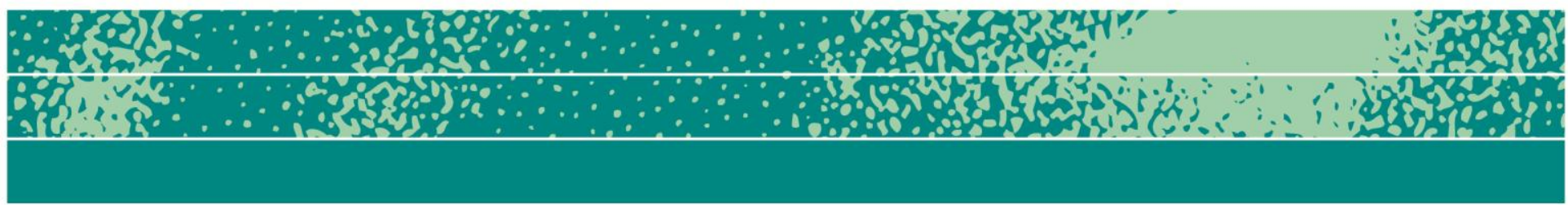

\section{Moulding Knowledge into a Legal Complex: Para-ethnography at the Swedish Tax Agency}

\author{
Lotta Björklund Larsen
}

\begin{abstract}
The foundation of a functioning welfare state is a tax system that is widely accepted and considered to be fair and legitimate. How and by what means a tax collecting agency interprets the laws are thus seen to have an impact on taxpayers' willingness to pay. This article addresses the various practices, knowledge and forms of data that the Swedish Tax Agency applies in a risk assessment project, against a background of the Agency's on-going endeavour for legitimacy. This article shows how its methods not only entail taking account of massive amounts of Tax Agency regulations, research, and statistical results to follow, but also reveals how stories, hunches and examples from media and everyday life coalesce to affect those methods. So, too, with the ethnographer's role: how is she to deal with knowledge production within a governmental organization whose employees read, and also learn from, what she writes.
\end{abstract}

Page 1 of 23

JBA 2(1): 209-231 Fall 2013

(C) The Author(s) 2013 ISSN 2245-4217

www.cbs.dk/jba

\section{Keywords}

Taxes, fiscal anthropology, legitimacy, methodology, bureaucracy, Sweden 
The foundation of a functioning welfare state is a tax system that is widely accepted and considered fair and legitimate (Lodin 2007; Nordblom 2008). ${ }^{1}$ The Swedish welfare state has a long and strong tradition in this respect, with its services mainly financed by income taxes. How the Swedish Tax Agency collects a considerate amount of money from each taxpayer (Sweden has one of the highest tax levels in the world), while still being regarded as one of the governmental institutions towards which Swedes are most positive (Ekonomistyrningsverket 2012), makes it an interesting object of study. ${ }^{2}$ The Tax Agency is quite aware of its vulnerable position and is concerned, for example, whether its existing 'rules and practices' might be deemed unnecessarily complex. In order to continue to be perceived as even more reasonable and equitable by the taxpayer, it continuously adapts the system it uses (including procedural guidelines, information, feedback to politicians and governmental institutions, cooperation with accounting and audit firms, and so on) in order to simplify taxation procedures (Skatteverket 2011:118). How and by what means the Tax Agency interprets the tax laws are thus seen to have an impact on taxpayers' willingness to pay.

The focus of this article is on one of the Agency's risk assessment projects that concern a certain selection of taxable entities as cost deductions. ${ }^{3}$ This project originated in the Analysis Unit Analysenheten) at the headquarters of the Swedish Tax Agency in Solna, outside Stockholm. I will use this project to explore the various types of knowledge the Tax Agency holds in the context of its on-going endeavour for legitimacy in Swedish society. In so doing, I will also cast light on the ethnographer's role: how to deal with knowledge production within a governmental organization whose employees read, and also learn from, what we write (Holmes and Marcus 2008, 82; cf. Brettell 1996).

The various practices, knowledge and forms of data that an institution such as the Tax Agency apply are here seen to affect societal economy in a broad sense (Campbell 1993; Marques 2004; Martin, Mehrotra, and Prasad 2009; Roitman 2005). This approach focuses on economic processes, rather than on the economy itself, through which behaviour, organizations and institutions are constituted as 'economic': that is, on how they are identified

\footnotetext{
${ }^{1}$ An early version of this article was presented at AAA Montreal 2011 in the panel "A Fiscal Anthropology? Ethnographic Approaches to Taxation Issues" and I am most grateful to comments by co-panelists Jose-Maria Munoz, Mireille Abelin and Karen Boll as well as those from discussant Janet Roitman. Ulf Hannerz has continuously been supportive of my fiscal anthropological endeavour; colleagues Corinna Kruse and Karin Thoresson gave as always good feedback and so did the anonymous reviewers of JBA - thank you all. My greatest thanks however go to my informants at the Swedish Tax Agency who have most generously given me insight into their deliberations, shared their emails, and in the true spirit of para-ethnography also commented on this text.

2 This survey found that governmental bodies that give out money are the least likable, e.g. CSN, the Student Aid, and Försäkringskassan, The Swedish Social Insurance Agency

${ }^{3}$ The exact nature of deductions will not be disclosed as the resulting report of this project was not made public.
} 
in financial terms (Çalışkan and Callon 2009; Caliskan and Callon 2010) or economically formatted (Poon 2008). Analysing processes aligns with the Tax Agency's continuous aspiration for increased acceptance of its evolving tax system by Swedish taxpayers.

\section{Methodology}

This risk-assessment project holds together multi-local fieldwork that has taken place in different professional environments, each demanding various field methods (Hannerz 2001; Hannerz 2006). The method applied derives from policy anthropological studies, where the objective is to monitor how guidelines are shaped and used in practice (Nyqvist 2008; Garsten 2008; Thedvall 2006), but the focus of this article is to identify the step prior to this formation and application of guidelines. It thus engages with the research phase, and more specifically with the type of data the analysts demand and use. I have followed this project for almost three years: from its initiation to rolling out in a daily practical audit, by way of research, the forming of policies, and publication of a report. Input comes from my participation in about 50 meetings at the Analysis Unit lasting from 30 minutes to two consecutive days, all recorded and transcribed; participant observation at various offices in Örebro; more or less formal interviews with about twenty employees; and a considerable amount of research material, background reports and written communication between the analysts,

The methodology thus entails getting to grips not only with massive amounts of Tax Agency regulations, research, and statistical results, but also with various stories, hunches and examples from media and everyday life that coalesce to affect them. In the background lingers a law, ${ }^{4}$ that at times is stalwart and at other times irritating. To understand these cost deductions, analysts apply 'common knowledge' (Valverde 2003: 21). Such knowledge is not in contradistinction to other, established, types of knowledge, but is, rather, a pragmatic morphing of an array of diverse explanations and socalled facts. While the focus is on the work that originates from this small group of analysts, their knowledge supposedly mirrors the views of the Tax Agency itself. The results will, if not shape, then at least impact, the work done throughout the Agency. I thus use the idea of a 'legal complex' (Valverde 2003), not enforcing the binary oppositions of science versus experience, but as an example of where these diverse types of knowledge are pragmatically moulded into new insights, if not a new type of knowledge. Importantly, there is no one type of knowledge found in one particular locality or milieu, but diverse types of knowledge that compete and reinforce, make and shape, support and contradict each other in order to provide new insights within this field.

\footnotetext{
${ }^{4}$ Following the 1991 tax reform, all exchanges of services of value ought to be subject for tax assessment when deemed to constitute income - regardless if money, a service in return or material objects. This encompassing approach obviously leaves room for interpretation (Skatteverket 2006:4).
} 
To emphasize more explicitly how 'common knowledge' is found, I also draw upon the notion of a para-ethnography in the vein of Holmes \& Marcus $(2005 ; 2006 ; 2012)$. This notion resolves a number of issues concerning the origins of data including the impact of my own research. Para-ethnography offers a way to study ethnographically experts operating in complex societies - not in their entirety as social beings, but in their professional role, and especially through their practices when carrying out their job (cf. Nyqvist 2008). It provides a way to assess critically the type of knowledge these professionals use, and to move emphasis from their specializations' epistemology to the 'anecdotal, hype and intuition' (Holmes and Marcus $2005,237)$. The way the analysts in the core project group, the Task Force, carry out their chores is thus a striking example in itself of an application of para-ethnography (Holmes and Marcus 2006, 35). Its members certainly make use of the disciplinary knowledge in which they are trained, and of previous research reports (as well as a few external research reports) that have built up the Tax Agency's knowledge of tax non-compliance. They cite newspaper articles, refer to friends' practices (if not always explicitly), take up examples of discussions at coffee breaks, and in general try to keep up with what is going in the society they live in.

In addition, they have read and refer in conversation to my earlier work (Björklund Larsen 2010; Björklund Larsen 2011), which is my admission to this otherwise fairly closed organization. From a naïve positivist standpoint, this would thus be considered a contaminated field. However, this fact points out a reality that many researchers of contemporary institutions and organizations have to address (Holmes and Marcus 2008, 98), as well as an awareness of (Swedish) academia's third task. ${ }^{5}$ Our informants read and react to what we write and also make use of our presence when we do research: for example through directly posed questions, or through the more informal discussions at luncheons, coffee breaks, to ask for lectures, and even resulting in a course introducing social scientific 'tools' for all analysts at the Agency. Thus does both a collateral (cf. Maurer and Mainwaring 2012, 182) and collaborative (Holmes and Marcus $2012,127)$ type of knowledge evolve.

In the practical carrying out of this ethnography I was inspired by the social studies of finance, where not only actors, but also knowledge and technical equipment matter (e.g. Callon 2007; MacKenzie 2009). Although each piece of data can be traced chronologically - since each document, field note and interview has its specific origin - the image of piecing together a puzzle to which the Tax Agency used to refer in an earlier project about informal work (Skatteverket 2006; 2007) is not really apposite. Like Karen Boll in her study of Danish tax compliance (2013), I am also intent on avoiding the 'perspectivist' assemblage of a piecemeal ethnography ready to be seen, collected, transcribed, analysed, and written about. In this vein, I

\footnotetext{
5 The University's responsibility to share research insight, apart from the more general tasks of teaching and research
} 
recognize the things used to perform these practices (Callon, Millo, and Muniesa 2007), as well as the places where they are performed (Murphy 2013; Zaloom 2006), in order to understand how knowledge is formed. Although these approaches make all knowledge claims have equal standing (cf. Valverde, Levi, and Moore 2005, 89), in this article we will see that any specific legal interpretation precedes any other knowledge (Latour 2010; cf. Riles 2010). The construction of knowledge within this project is thus seen as an iterative process.

So the project is an example of how physical agency, technical devices and knowledge coalesce. Yet within the concept of physical agency is one of a human being in full, and I want to acknowledge his or her diverse capacities for action. I do not follow these people outside their workplaces (cf. Boyer 2008), but I do pay attention to their way of being, to their different ontological capabilities, and to how they influence one another. I can only bow to Boyer's manifesto that we should attempt to know the humans behind the expert shield, follow their professional development, reflect on the anthropologist's impact, and pay attention to the various forms of knowledge they embrace - and not just to rationalist argumentation (Boyer $2008,44)$. In addition, I also recognize the importance of the environment for human behaviour (cf. Zaloom 2006, chapter 1).

So what this article deals with are diverse places and diverse types of data. The project takes me to four main localities, each supplying a specific set of information, which also organizes the first part of this article. Firstly, I will introduce the reader to the Task Force with whom I follow on-line and physical meetings. The requests for analysis, knowledge and data originate in the Analysis Unit to which the Task Force members belong, but are carried out in different localities, each applying its own method(s). Secondly, I conduct participant observation and interviews at R.C., a private research consultancy, which carries out an extensive telephone survey on behalf of the Analysis Unit, and at the local Tax Agency's Random Audit Control department in the city of Örebro. Lastly, I present my own computer's gathering of all e-mail correspondence, which I am copied in on, between the Task Force's participants regarding the project. It is a type of 'polymorphous engagement' (e.g. Gusterson 1997, 116) that takes me wherever the project is professionally carried out. In contrast to the Gusterson approach, I was invited to follow the project, but there are still certain places where I am denied access, a point to which I will later return.

In the second part of the article, I will return to the Task Force and discuss how these collections of data are further reflected upon, shaped and remoulded with other types of knowledge. These new findings are either assembled into yet another sub-report or set of new questions, adding yet one more round to an external source before being made part of a final report. In the subsequent analysis, we will see examples of how the different types of established facts, the technical resources, and employees' perceptions of what goes on in Swedish society, make up this 'legal complex'. 


\section{The Swedish Tax Agency and one of its risk assessment projects}

There is only one Tax Agency that organizes all tax collection in Swedish society. Until 1987 the tax administration was part of the provincial government, länsstyrelsen, when the task was reorganized into independent agencies, one for each province. In 1999, the 24 independent provincial agencies were merged into ten regional Tax Agencies, which in turn became one national Agency in 2004. The aim was national standardization, in order to ensure that tax laws were homogenously interpreted, and that all tax payers got the same message and received the same treatment. The Agency's head office is located in Solna, a suburb of Stockholm, where it occupies almost an entire city block. According to Agency lore, when the building was under construction in the late 1960s as a factory for the light industry, Gunnar Sträng, one of the architects behind the reorganization of the Swedish Tax authorities and the Ministry of Finance at the time, passed by in a car. He apparently exclaimed, 'this is what I want for a headquarters' and Mr. Sträng being Mr. Sträng, the state subsequently acquired the construction site and the half-finished building was adapted for office work. ${ }^{6}$ The initial purpose of the building is still apparent as the floors slope and there are pieces of cardboard and wood, thin books, and other sorts of supports under many bookshelves to prevent them from falling over. ${ }^{7}$ Evening out the slanting floors would have required so much floor-filler that the building would have collapsed under its weight. The original purpose for the building, its location in a former industrial area, and the red brick façade commonly used for factories seem all the more fitting as 60 per cent of all Swedish taxes collected derives from workers' salaries.

The head office is where the Analysis Unit is located. Amongst its duties is performing risk evaluations. These evaluations address issues that might prevent the Tax Agency from carrying out its instructions and collecting taxes as ordered by the Swedish parliament and instructed by the Ministry of Finance. The definition of risk is quite extensive, and issues are described as originating both externally and internally (Skatteverket 2005). External risks are events in society that are deemed to impact the ability and will by citizens to pay taxes. These could be events such as a financial crisis, changes in laws that may create loopholes, or structural changes like the expanding number of self-employed in the country. ${ }^{8}$ Internal risks include

\footnotetext{
${ }^{6}$ Interview with former Director of Information, Björn Thärnström.

7 Since December 2012, the Analysis Unit has moved to a new building next door. Their former offices have been remodelled to accommodate colleagues currently residing in the city of Stockholm.

8 The yearly tax return for employed people is now highly automatized. All tax payers get a complete tax statement that is pre-filled out with income, interest payments and other information that is required by employers, authorities and credit institutions to report. Most tax payers just check the figures on the pre-filled tax statement and simply accept it with an electronic signature, in some cases after making a few changes to the statement over the web. These income returns are obviously easy to verify and check. For self-employed people, the tax return situation is obviously different and more complex. For example, the tax return for
} 
topics such as a 'wrong' interpretation of the law, requests originating from other departments (especially the legal one), and lacunae in control procedures and organization. The initiation of risk evaluation projects derives from many sources: inquiries from authorities, tips or questions from the public, and even from discussions at coffee breaks. A risk evaluation usually runs as a longer project involving diverse knowledge, assessments and evaluations.

For the project with which my fieldwork was concerned, the head of the Analysis Unit ordered it initially, but gave the Task Force significant latitude in carrying it out. The Task Force comprises two analysts from the head office and two to three of their colleagues from diverse regional offices, underscoring the homogenizing knowledge endeavour of the Tax Agency. The project puts forward five broad questions that the Task Force should address, all of them regarding the issue of cost deductions for a specific type of commercial entities.

- Are the regulations unclear?

- How common are obviously faulty deductions?

- How are other taxable entities affected?

- Are there consequences resulting from the rapid expansion of these entities?

- How to identify the risks with this issue (for the Tax Agency)?

These questions are addressed through diverse 'field studies,' as the Task Force commonly refers to its research. In the following we will first visit a meeting with the Task Force and then go on to see how its methodological undertakings are carried out finding facts in the chosen fields.

\section{Constructing knowledge at the Analysis Unit}

Every time the Task Force meets at the Tax Agency, or when it has planned on-line meetings, I am invited to attend. ${ }^{9}$ The Task Force consists of up to five analysts: Julia and Lars from the head office, and Gunilla, Svenne, and Per, who each come from different regional offices. ${ }^{10}$ Its face-to-face physical meetings take place in a meeting room at the Agency's headquarters and the on-line meetings in each participant's own office. In either case, I am picked up at the reception where there is a visitor's badge waiting for me. I am let in by the security guards and made to wait in a well-lit and open visitors' area. From the quite dark, narrow, and basement-like reception desk area, the

self-employed is manually filled in.

${ }^{9}$ Sometimes the on-line meetings are not planned, but occur as a result of an urgent issue that they want to discuss. Then I am left out. For the few other meetings that I have not been able to attend, the coordinator has very nicely agreed to record them for me and then sent me the voice file.

10 Julia and Gunilla did not participate in the part of this project when most knowledge was amassed. They are therefore left out of this description. In the conclusion to this article, they are referred to and will be included in further writings on this project. 
atrium unfolds to give an impression of space and unlimited thinking. However, it is only five flights up before the glass ceiling abruptly interferes. As a result, the initial impression of unlimited space is quite fleeting, and quickly changes to the reality of an enclosed space, surrounded by the same brown brick walls that make up the atrium. It is always noisy there. Employees and visitors pass, alone or in groups, with folders, or the occasional portable PC or iPad tucked under their arms. A door is clicked open with an employee's pass, there is a shuffling of footsteps, and their conversation abruptly becomes inaudible as the doors close shut behind them.

In the middle of the atrium, one broad flight of stairs invites employees and visitors up to the coffee hall, Nöterian (a literal translation is 'the Nut Place'), ${ }^{11}$ where I am usually invited to grab a coffee on the way to the meetings. Skipping the elevator, we walk two flights up and into the corridors that stretch out surrounding the atrium. Tiny office cubicles or smaller areas of office landscapes align the corridor, interspersed with meeting rooms of various sizes. All offices and meeting rooms have windows out onto the corridors, making the place look larger and more transparent than it is in reality. Most meeting rooms are occupied, and one or two bored attendees glance at us as we pass outside. It is a very typical Swedish office milieu: well-lit, a mixture of colours on the walls, curtains and decorations that do not offend the eyes, but leave no impression and are awfully difficult to recall. The office furniture has the customary beech-coloured laminate with adjustable chairs in bright coloured fabrics.

This is an office milieu that does not stand out and clearly has connotations with historical meanings of work in Sweden. The premise of the Tax Agency is thus an example of how design impacts social interaction (Murphy 2013). First of all, the buildings connect to work and industry in a broad sense - through both its location and construction in red brick. Secondly, it is by no means an example of 'aesthetic' Swedish design (Murphy 2013), but a display of a typical worn-in, contemporary everyday Swedish office, and thus offers a milieu to which most Swedish office workers are accustomed. These points added together can make the building an illustration of the Agency's vision of Sweden as 'a society where everybody wants to do the right thing' or, perhaps more specifically, 'do one's fair share'.12 Thirdly, as we will see, the building's glass ceiling suggests that not just any knowledge is acceptable. This leads to agree with Murphy and Zaloom about the importance of place on the people who work in it: 'it is something with a social life of its own that can be pointed to and articulated and argued' (Murphy 2013,129). Seeing place in this sense contributes to our understanding of 'the critical mechanics that drive Swedish politics and

\footnotetext{
11 Nöterian is named after the city block 'The Nut' where the building is situated.

12 On the Swedish Tax Agency website there is a motto prominently displayed: Vår vision är ett samhälle där alla vill göra rätt för sig.
} 
society but also the more general, often uneasy, relationships subsisting between people, power and the things of the world' (Murphy 2013, 129).

When they convene in person, Task Force members usually start chitchatting for a few minutes, seemingly enjoying one another's physical presence, instead of seeing each other by way of a screen in the more commonly held video-meetings. The Tax Agency operates in a cost-conscious environment, so that taking a plane or train to Stockholm is not permitted on a weekly basis.

The meetings are as informal as the environment, as is the dress code of the attendees. Lars is the meeting organizer and a gentle theoretician who never pushes his opinion until he has listened to all the other participants and has thoroughly considered an issue. The guy from the North of Sweden, Svenne, digs out anecdotes and episodes from his long experience. He has a strong accent from his region, is street smart and a word equilibrist. In the beginning he found everything very interesting - not mockingly, but truly intrigued by the smallest of issues. He continuously offers examples from reality, as well as new metaphors to elucidate the issues they discuss. On his own increasing insight into their quest, he once said: 'Before, I felt like this project consisted of 40,000 islands with shitty communications among them. Now I feel that they are getting increasingly connected, and that there are regular boat services between some of them.' Lars smiled suggested that there were perhaps even bridges between the islands. 'Not yet, but in due course', Svenne objected. 'There will be bridges. Right now, some of the islands only have a row-boat that departs monthly'.

When Per came on board, so did the worry of performing proper research. He repeatedly asked me, the ethnographer, how research is done in the academic world - a question I tried to ignore. One venue he then proposed was to re-examine all issues previously agreed upon as hypotheses. The others were initially reluctant, but as they are always eager to get new insights, they agreed and all attained insights were reformulated into hypotheses.

These meeting anecdotes are but a few examples of the manifold types of knowledge shaping an outcome. ${ }^{13}$ The analysts are very dedicated and enjoy discussing and deliberating, taking up previous conclusions and insights from the Tax Agency's reports as well as presenting new ideas. They are not afraid of using metaphors, new analytical methods, or stories from everyday life. There has seldom been a specific stance for a certain point of information or an argument about who is right; this consensus-driven setting seems also very Swedish (Daun 1989; Ehn 1983; cf. Rosenberg 2002). There is thus a careful moulding of diverse facts and ideas, but also constant attention to keeping within the aims of the project.

${ }^{13}$ Julia and Gunilla did not participate in the part of this project when most knowledge was amassed. They are therefore left out of this description. In the conclusions of this article, they are referred to and they will be included in further writings on this project. 


\section{A survey of Swedes at a Research Consultancy's call centre}

One of the first issues the Task Force members dealt with was to prepare a survey regarding Swedes' attitudes towards cost deductions, and work on various versions of this survey took up most of the first six months. The Tax Agency's previous experiences of performing such surveys, as well as the Task Force members' own insights and knowledge about these cost deductions, governed their deliberations. Which type of examples and issues were to be provided? How to find a mixture where extremes were not too obvious? As Svenne put it: 'We cannot have a Boeing at one end and a Toblerone at the other'. ${ }^{14}$

There were many other questions to be dealt with. Would the scales expressing agreement or disagreement with the statement consist of three, four or five points? In which order should the questions appear to provide most replies? Much elaboration concerned the initial tone of address and assurance of anonymity. And which method would ensure most feedback: a mailed enquiry, a telephone survey, or even focus group interviews? The discussion surged back and forth in meetings and in e-mails concerning the type of knowledge the Task Force wanted and the perceived ease of analytically penetrating the results. The final choice was also influenced by ease of execution and cost consciousness.

The Task Force finally settled on telephone interviews as it was deemed less likely that a respondent would just hang up whereas she might well throw a written questionnaire into the nearest available rubbish bin. A Research Consultancy, RC, won the contract to perform the survey. The proposed enquiry went through one internal and several external reviews before being finally approved without any major changes. ${ }^{15}$ The project manager at RC praised the Task Force, saying that it was more thoroughly worked through than most other surveys RC received from clients.

\footnotetext{
${ }^{14}$ Svenne was here referring to former Swedish Prime Minister Mona Sahlin's once fatal mistake of paying for a Toblerone chocolate bar with her work credit card. In 1995 she was Labour Market Minister and the urge for a sweet using the wrong card forced her resignation.

15 It was expected to receive pro forma approval from NNR, Näringslivets nämnd för regelförenkling, but instead became a drawn out and costly procedure. NNR is The Board of Swedish Industry and Commerce for Better Regulation. It is a non-profit body and has fifteen business organizations as members, to which 300,000 companies, representing virtually all size categories and sectors, belong. NNR's function is to work for fewer and simpler business regulations and to minimize the extent to which companies are required to report information. NNR's principal tasks are to consult with public agencies before they impose new reporting obligations on business, to coordinate the business sector's scrutiny of the Government's, public agencies' and government committees (from www.nnr.se/inenglish.html). NNR thought the proposed survey was an unnecessary intrusion into its members' activities. The director at RC who was involved in the process was quite surprised by the NNR objections, and countered that NNR probably never sees 99 per cent of public authorities' surveys done with the private sector. In the end, no major changes were made to the survey.
} 
I spent a few days at the RC's Call Centre, listening in to the calls and performing interviews with a few employees, the project manager, and the partner who had negotiated the deal with the Tax Agency. About ten people - mostly students - worked on this project. They all had nice voices, wore headsets, and were seated in front of screens where phone numbers randomly appeared. The questionnaire and the log of who had called whom and at what time were all computerized. After providing the respondent with some information regarding the reason for their call, they began the actual survey. The questions posed regarded what the respondent thought about the subject: the scope, causes and consequences of the types of costs that were in focus. There were about five choices for respondents to select from, plus one of 'Don't know/no opinion'. However, the woman I sat with never mentioned this last option. It was something respondents had to say themselves.

One call started with a young girl at the other end of the line replying that the contact person was never on site. She offered a cell number, to which a man replied, though quite reluctantly when he learned about the purpose of the call. He had a heavy dialect and gave off an impression of ineptitude and ignorance. 'It's the girls in the office who know these things'. He responded passively and slowly, starting each answer with 'I think...' From the initial perception of his coming across as rather dumb, however, he began to sharpen his answers and seemed increasingly on guard as the questionnaire came to an end. He really pondered over his final replies. Another call to an elderly woman was quick and efficient. She never hesitated, but provided answers without ever expressing a doubt, indicating that she knew the subject well.

There was a sense of urgency at RC. The callers talked quite fast, clicking impatiently on the mouse to get up the next number to call, and their mouths seemed to utter the questions learnt by heart without reflecting on what they were saying. They were supposed to make four calls an hour (the manager said 0.7 to two an hour) and the woman I sat with made at least five. She had a nice tone in her voice, but was completely uninterested in whom she was talking with. Once RC finished contacting the randomly selected 2000 entities, it tabulated results in an SPSS file ${ }^{16}$ and sent it to the Tax Agency for analysis. 1074 interviews were made out of the 2000 people called - a fairly okay result, according to RC's manager.

\section{Hidden exchanges at the Random Audit Control}

If I am at risk in being seduced by the creative shaping of ideas and knowledge while following the Task Force, visiting the office that performs the Random Audit Control - referred to as Slumpkontrollen_(the Random

\footnotetext{
16 SPSS, Statistical Package for the Social Sciences, is a common file format for predictive statistical analysis.
} 
Control) ${ }^{17}$ in the vernacular of the Tax Agency - supplies a much stricter procedure, almost a repetitive script that is open to power negotiations. A Random Audit Control is the backbone of such a risk assessment project and it was decided upon even before the order of the project was finalized. The details were shaped in collaboration between the Task Force members and the managers at the Random Audit Control.

This department is located at the regional office in Örebro, a mid-size city which is situated a two hour train ride west of Stockholm. The office is a brief walking distance from the train station, and consists of an L-shaped, functionalist and ordinary office building. The entrance at the fold of the $\mathrm{L}$ gives off the feeling of making a visitor welcome, as the building seems to embrace the visitor. This feeling, however, is abruptly cut short by locked entrance doors and a small sign saying that the reception has moved, but with no hint as to where it might have moved to! No phone number is listed, nor is there a door bell. I have to call a private number on my cell, and my assigned contact comes down and fetches me. Her personal warmth makes me feel quite welcome after all, although I feel as if I am under disguised, scrutinizing eyes when sitting down with department members for their regular Monday morning coffee at $9.00 \mathrm{am}$. But people are pleasant enough and I chit-chat with the project manager I interviewed a few months ago, and nod and exchange a few words with some of the other twenty or so department members.

To perform a random audit control is a recurrent practice at the Tax Agency. The purpose is to 'fill identified lacunae of knowledge' and 'create an unpredictable control mechanism'. ${ }^{18}$ A random audit control takes place among a statistically selected group of entities, chosen by various criteria: type of legal entity, business sector, demographic segment, and so forth. It is part of the Tax Agency's yearly work procedures, but is also often used as input into the Analysis Unit's projects. The office in Örebro has had a lot of experience in executing these controls and the manager of this particular project coordinates the audits at all four participating offices.

A successful random audit control is one that obtains solid results. Planning is essential, and the aim is that everybody will perform their audit in the same manner: looking for the same things, evaluating discrepancies in a similar way, and reporting them in an orderly and consistent fashion. It is a standardization of working, thinking and talking. Random Control had quite a long discussion with the Task Force over which entities should be subject to this audit to ensure it would provide a meaningful result. First of all, the subject concerns a specific kind of legal entity. ${ }^{19}$ For each one, there must be a minimum amount of the yearly cost deductions, but there is no limit on

\footnotetext{
17 The formulation 'Random Control' is in itself a contradiction in terms, although here random refers to the statistical selection and control to the audit procedures.

${ }^{18}$ Skatteverket Uppdragsbeskrivning slumpkontroll as of 2009.10.29

${ }^{19}$ One of the restrictions for my following of this project is that I cannot disclose the project details until the results are published. The project selections can therefore not be fully revealed, but this limitation has no relevance for this article.
} 
turnover. The auditors' travelling costs should be kept at a minimum, so the entities should not be located too far away from Örebro or the three neighbouring offices that also participate in executing the audit (the Tax Agency is, as noted earlier, cost-conscious). Working with a confidence interval of ten per cent means that they have to audit 383 entities, and have settled on a more round number of $400 .^{20}$ This random audit is by far the largest they have ever performed. 4000 man days are allocated, and about 40 auditors take part. The head of department had pointed out to his colleagues that, although the audit might be seen as addressing petty sums, this project is probably the closest they will ever get to being able to impact practices in society, or in the Tax Agency's forms ${ }^{21}$ for that matter.

After morning coffee, the weekly department meeting starts. The project manager informs all present about the status of audits; at the time of my visit there were 82 audits accomplished and 49 more under way in Örebro, out of a total of 400 statistically secured selection from the national database. Participants pose a few general questions, mainly of a procedural nature, and then head off 'to work'.

The confidentiality issue regarding my following of the project, and especially my visit to this office, has been debated on several occasions and at various levels. ${ }^{22}$ There are several reasons why it is interesting that this happens at the very nexus of an identifiable and physical, at least verbal, contact between the Tax Agency and its audited subjects. First of all, the Task Force members are subject to quite intimate exposure of how they think when they let me follow their reasoning and deliberations, as well as their successes and set-backs. Arguments over issues are perhaps toned down due to my presence, but they expose themselves and throughout my following of the project, there have been very few disagreements in these consensusdriven deliberations. Secondly, I have signed a confidentiality agreement, as all employees do, which ought to protect the Tax Agency from my disclosing any type of sensitive information. Thirdly, information on income and taxes paid is publicly available in Sweden. ${ }^{23}$ However, any audit under way is

\footnotetext{
${ }^{20} \mathrm{~A}$ confidence interval is in statistics meant to indicate how reliable a selection is compared to all entities possible to audit. In this case, it means that the audit of 400 entities is 90 per cent reliable in reflecting the results of an audit of all Swedish entities of this kind.

${ }^{21}$ Forms are an important subject at the Swedish Tax Agency. According to the law, (2001:1227, 1 chapter, 1, 3 and $4 \S \S$ ) the Tax Agency has the responsibility to make forms for diverse legal entities to declare their income. They also participate in the 'Form Days', where employees from diverse governmental institutions meet annually to discuss the latest developments in form making.

22 Those involved in the debates have been the project coordinator, the head of the Analysis Unit, the head of the random audit control, and a legal expert at another regional office.

23 This means, for example, that anyone can visit the local Tax office and borrow a public PC with access to income statements as well as tax payments. The tabloids often make use of this information, listing the 100 highest paid individuals in 'your municipality' and publishing similar rankings.
} 
strictly confidential and any individual has a legal right for identity protection, until a revised audit is agreed upon and made public.

But most important is the sensitivity issue. I am told that it is out of the question for me to accompany the auditors on their visits to the selected entities, as audit visits are one of the most delicate tasks the Tax Agency performs. Just having two visiting auditors can be seen as an intrusion, so bringing along a researcher, too, poses too much of a risk. This is somewhat contradictory, given that searching for hidden transactions was not only an issue when dealing with tax-cheaters, as I had learned in my previous fieldwork. After all, they spoke willingly about their illegal yet licit purchases in order to justify them (cf. Björklund Larsen 2010). And yet, in their foe's den, the Tax Agency, the same, questionable types of transactions are now hidden for me. This secrecy manifests itself in various ways. In the offices, a set of binders (there is one for each entity subject to audit), have been turned with the spine back to the wall, and my contact ensures that I do not overhear any conversations taking place in the corridor outside the office. A compromise is finally proposed. I cannot sit in on a 'live' audit within the department; instead I have to make do with being shown the educational material.

The law protects the taxable subject from other citizens' gaze, including that of this researcher, until a final audit revision is made. How the Tax Agency moulds this part of the legal complex, outside the protected environment of desktops, conference tables and internal documentation at the Random Audit Control, is thus not possible for me to follow and write about. The para-ethnographic endeavour of a legal complex stops short here: both for me and for the Tax Agency.

Instead I am taken through all the steps in the audit procedure; the queries and memos auditors make in diverse data systems; how they create a binder with physical documentation; the logbook which records each step of the audit; the diary registrations procedure they have to go through at each step of official contact with the audited entity; and the diverse letter templates that are used in written communications. There are in total seventeen checklists, procedures, information materials, and questionnaires to follow during phone contacts and visits. There are ten working days allocated to each audit, of which two-thirds are concerned with administrative tasks and one-third with the actual audit. The head of the entire audit department signs off and thus actively participates on four occasions: when the letter stating 'decision for audit' to the selected entity is sent out, ${ }^{24}$ when the audit plan is approved, when the time for decision of audit is made, and when the final PM stating the changes in taxation is distributed. The involvement of the diverse managers, as well as the diary registration, is viewed as a quality assurance; it inhibits faulty procedures, hasty decisions, and wrongdoings.

24 They do not want to audit entities recently contacted. 
A procedural aim of this audit is to negotiate as much as possible on the phone, and the initial call is regarded as crucial for how the entire audit will proceed. The document for this initial telephone contact is, therefore, thorough and includes many explanatory points: what an audit means, the time allocation planned, the need for cooperation, guarantee of full secrecy, and procedural steps. There are questions about the activities of the audited entity, and more specifically the book keeping procedures. Finally, they inform the selected entity about the upcoming visit, what it entails, and what material the auditors wish to bring with them back to the office.

The standardization at Random Control also manifests itself in the recurring meetings regarding what to allow as deductions. I am allowed to sit in on one of the many discussions between a Tax Administrator and more senior colleagues. The discussion takes place on the sofas at the informal meeting place in the corridor, and my presence makes it absolutely impossible for any of them to disclose who the audited subject might be. The Tax Administrator needs to discuss a few items with the ordained Tax Auditor who is higher in rank. The subject for discussion is an on-going audit of a PR-consultant located in Stockholm. He has a few questionable expenses. Amongst them are travelling receipts: 3331 krona $^{25}$ in SL-remsor (the Stockholm public transport ticket slips) and 5053 krona in taxi fares. ${ }^{26}$ None of these can be directly linked to his business assignments, and he cannot remember whom he visited using the ticket slips. They are certainly not for commuting to work, as he bikes the short distance $(500 \mathrm{~m})$ from his home to his office. He claims that sometimes there has been a need for a taxi, when he has had to take his computer with him, or the occasional poster screens that he makes for clients. Events, like celebrations and anniversaries for shops, take place at night which should explain the taxi receipts from nightly rides.

Although the burden of proof lies with the taxpayer and any claimed deductions should be supported by receipts or similar documentation, it is underscored that the Tax Agency needs to be reasonable in its decisions. An often repeated word, 'being reasonable' is probably at this point also intended for my ears. We do not want to appear petty, they say, but allow for deductions that could be crucial for the type of work he does. It is thus reasonable to say that some of these travel expenses have occurred while he works, but the question is how much? They decide to take it up with the Chairman of the local Tax Board. ${ }^{27}$

The next day they meet the chairman, a bearded man in a chequered flannel shirt who has a relaxed, yet imposing presence. We sit in the same

\footnotetext{
${ }^{25} \mathrm{~A}$ krona is the Swedish currency and there are about nine Swedish krona to one euro.

${ }^{26}$ All taxi receipts are printed from a fare meter indicating driver and car, start and end time, the distance covered, price and total price, VAT and the type of payment execution.

27 The Tax Board is the authority where all decisions concerning changes to the tax statement are declared as final before the PM is sent out to the audited person/entity.
} 
sofas as yesterday, he on the same side as me. The case is presented, and the chairman asks some questions about the consultant's business, his office, turnover, if he has any employees, and so on. The chairman also asks for supporting documentation. They have talked with the consultant and pointed out the need to provide proper receipts and correct travel expenditure reports. The chairman also insists on being reasonable, to calculate 'a ballpark figure' and allow for costs pertaining to cell-phone and computer usage, and some travel costs even if they take place at night. The consultant has a decent turnover which supports the claim that he actually does business. They discuss and reject some other demands for deductions, and then the chairman returns to the local travel receipts concluding that he, the consultant, either needs to provide supporting documentation or 'you have to 'smack on' some amount - perhaps half?' The auditors assert that they want to come to a reasonable decision while discussing the entity who is subject to audit - but who in reality does not have much possibility of objecting. The PM (a proposal for the final public decision) that is sent to the audited entity is not only controlled and signed by the head of the department, but is also sanctioned by the local Tax Board.

There is an eerie feeling of power being wielded in this discussion. Being reasonable is perhaps best described as a type of soft power in everyday life (Keohane and Nye 1998; Hannerz 2011, chapter 12), moulded between knowledge about everyday Swedish business life, interpretations of the law, and perceptions of legitimacy. It is a praxis shaped by previous similar cases, but also by acknowledging human shortcomings and internal cost efficiency. This feeling of soft power adds a dimension beyond paraethnography, and pinpoints 'the study of areas outside the binary opposition of expertise versus everyday knowledge' (Valverde 2003, 22). It is where the fuzziness of practicing the tax law is most pronounced.

\section{Mail correspondence and other documents as ethnographic data}

In between meetings, the project's main mode of communication is via email correspondence, which I am copied in on. These written messages address everything from the mundane calling for meetings, or posing of a single question, to the more frequent distribution of versions of report drafts, as well as research articles deemed useful as input. These are made into documents and thus become part of the ethnography, in addition to transcripts from meetings like the ones described above, interviews, research reports, and other field notes. These documents do not stand alone (cf. Riles 2006) but supplement verbal deliberations from the meetings.

The contents of the e-mails are in themselves a source of knowledge, but their attachments often contain more detailed information. Examples of such attachments are scanned newspaper articles, Excel sheets with diverse quantitative data, interview guides, compiled transcripts of interviews in which these guides have been used, and externally published as well as internal research reports. A notable type of attachment consists of different 
versions of sub-reports. Each one is an analysis of different issues relating to the five aims targeted for investigation, and will most probably provide background data for the final report. These report versions provide a complementary way to trace how knowledge within this project develops, as well as an example of 'how diverse types of agency are produced, stretched, or abbreviated through the medium of the document' (Riles 2006, 21; cf. Latour 2010). This mundane communication mode thus stitches the diverse parts of the project together and leaves a written trace of the Task Force's verbal deliberations, as well as showing glimpses of other departments' interest in the project (and its outcome).

\section{Moulding a legal complex at the Tax Agency}

To be able to follow the Task Force's physical and on-line meetings proved very helpful as they are performed in an informative and constructive mode. Prior to their meetings each member elaborated on the issues at hand reading, thinking and writing about them. At the meetings themselves, they explained how they have thought about a specific issue, how they have arrived at points they make, and provided insights to where their thoughts currently lay. These deliberations made it possible for the others to follow each line of thought, and were very valuable to the ethnographer as well.

In the quest for knowledge of these cost deductions, the traditional legal, economic, statistical and other reigning scientific modes of analysis (cf. Holmes and Marcus 2005, 237) were seemingly at the forefront. In reality, though, they seemed rather to be props supporting the Task Force members' views and deliberations as they paid attention to the Tax Agency's claims of legitimacy amongst the Swedish tax-payers. When these analysts interpreted the law, they did so taking into account their understanding of norms acceptable to most citizens creating a story that it was deemed legitimate to tell (Holmes 2009).

A feasible and well-established concept to use for the construction and trajectory of these types of knowledge between the Agency's diverse 'field studies' could be translation (e.g. Callon 1986). There have been many insightful descriptions of the changing nature of knowledge in different contexts and in particular the power structures that are made explicit via these translations (Latour 1987; Valverde 2003; Callon and Law 1997). But the word translation directs attention to dictionaries and established verbal equivalences so that there are a number of given solutions depending on which trajectory each type of knowledge takes. Choosing moulding in this article is an attempt to direct the reader's focus to the very careful attention paid by the Task Force to how diverse types of knowledge are formed. When the Task Force compared results from their work with already known facts, such as the result of an attitudinal survey, they can be said to reify it into a cast. We have also seen how they make use of established methods, but the results, insights and outcomes of each of these are then almost kneaded into new insights. Moulding is also applicable for the instances where a new 
insight is reached by careful shaping of diverse inputs into an entirely new form - for example, when they followed up the uncomfortable result from the random audit control with interviews with the auditors of how the procedures worked out in practice. Moulding connotes both the confirmation of already established knowledge and the creation of new insights.

The analysts who run each project know the law, have deep knowledge of performing audits, have read a reasonable amount of (external) research on the matter, and know by heart most of the internal reports produced previously. This knowledge is fuelled by friends' anecdotes, newspaper clips and stories from colleagues' experiences. In order to substantiate their claims, they delegate tasks to other localities, thereby getting 'facts'. To address tax-payers' values and norms regarding cost deductions, a research consultancy performed an attitudinal survey by means of phone interviews. Deliberations of many sorts went into the preparatory work for the survey and although each call was surrounded by relaxing chit-chat, there was no room for more than checks in the questionnaire. People's attitudes were thus transformed into an SPSS file consisting of numbers and percentages. These numerically presented attitudes contradicted the commonality of faulty cost deductions estimated by the random audit control.

Audits are at the very heart of the Tax Agency's practices and this random audit, like any other, has had a distinct focus and followed a strict procedural protocol in order to provide a 'solid' result. Checklists and regulations should be pursued and interpreted in the same way, but the auditors did not follow it to the letter (for example, when invoices were missing). Recurrent meetings and discussions between auditor, tax auditor, legal experts, and the head of the department morphed out a 'reasonable' interpretation applying common knowledge about the audited entities' business. Having revised the tax, the auditor aimed for a verbal agreement with the commercial entity before entering these carefully deliberated decisions as amounts in an Excel sheet.

When the result reached the Task Force, it created quite a stir. The number was not as expected. However statistically secured the selection was and regardless of how solid the results were, the analysts acknowledged that these digits begged for more explanation. Interviews with auditors followed and the numbers were thus nourished by examples from reality duly noted in the final report. As in central banks, '[w]ords in these circumstances perform the decisive function of creating countless contexts that can frame data series and statistical measures' (Holmes 2009, 411). ${ }^{28}$

The moulding of this 'legal complex' that I have sketched provides a more dynamic and flexible framework than the often homogeneous interpretation of one-discipline approaches or a reification of current laws

${ }^{28}$ Compared to the Central Banks that Douglas Holmes studied, a Tax Agency does not perform 'econometric projections' as he finishes this quoted sentence. 
(Valverde, Levi, and Moore 2005, 91). I will not contend that the risk assessment project I followed can be characterized as consisting of 'illdefined, uncoordinated, often decentralized sets of networks, institutions, rituals, texts, and relations of power and of knowledge that develop in those societies in which it has become important for people and institutions to take apposition vis-à-vis law' (Valverde 2003, 10), but I concur with Valverde that although there are certain legal demands, there are also many truths, and no one has privileged access to truth.

I want to underscore the fact that 'the knowledge process is plural and heterogeneous' (Valverde, Levi, and Moore 2005, 87), and so concur with their proposal of using not the singular 'knowledge' but plural 'knowledges'. However, not any usage of knowledge will do. Where there are specific regulations such as those concerning the mundane provision of fruit baskets and coffee at work places, which is tax-free for employees but seen as a taxable income for self-employed, auditors cannot do much about this perceived unfairness. These legally founded regulations will always override any other conclusions, regardless how unreasonable they seem. When the law stands in opposition to common practices, the Tax Agency has the option to point this out to politicians and law makers - an option, however, that it seldom takes.

We have also seen how the Tax Agency at different levels knows that the law cannot, and should not, be applied to the letter. Instead its employees refer to common knowledge which legitimizes their actions. The law also inhibits this researcher from exploring the entirety of the legal complex morphed out by the Tax Agency in its practices. Secrecy may be said to protect the tax-payer's identity, but it also protects the Tax Agency from being exposed in its supposedly sensitive audit visits to taxable entities. Between diverse types of expertise and everyday behaviour, this project thus takes on a para-ethnographic methodology, both applied by the analysts themselves, by auditors at the Random Control centre, and sometimes even by the RC surveyors. Referring to my work, it also includes me, the anthropologist, following the project. There is thus a constant assemblage of diverse knowledges in this project: statistical data from the attitudinal survey, the collective experience of audits, diverse academic disciplinary training (such as Per's insistence on applying hypotheses), as well as the Tax Agency's internal method courses, and information from the interviews they undertake. In addition, the anecdotes from employees' own and others' experience seem very important, as well as their instincts and hunches. Their deliberations are friendly and consensus seeking, often presented with wit and by means of metaphors. We have thus seen how a risk assessment project moulds various types of knowledge to be written up in reports, dispersed by mail for comments and further input, before finally being distributed within and outside the Tax Agency to effect changes in policy and taxpayer practices. 


\section{References}

Björklund Larsen, Lotta. 2010. Illegal yet Licit : Justifying Informal Purchases of Work in Contemporary Sweden. ACTA UNIVERSITATIS. Stockholm: Stockholm Studies in Social Anthropology N.S. 2.

———. 2011. 'Att ge, få och ge igen. Köp av svart arbete som uttryck för medborgarens relation till staten.' In Känslan för det allmänna :

Medborgarnas relation till staten och varandra, edited by Kerstin Jacobsson, 237-266. Umeå: Borea.

Boll, Karen. 2013. 'Mapping tax compliance.' Critical Perspectives on Accounting. Available online.

Boyer, Dominic. 2008. 'Thinking through the anthropology of experts.' Anthropology in Action 15 (2): 38-46.

Brettell, C. 1996. When They Read What We Write: The Politics of Ethnography. Westport: Bergin \& Garvey.

Caliskan, Koray, and Michel Callon. 2010. 'Economization, Part 2: a research programme for the study of markets.' Economy and Society 39 (1): 1-32.

Çalışkan, Koray, and Michel Callon. 2009. 'Economization, Part 1: Shifting attention from the economy towards processes of economization.' Economy and Society 38 (3): 369-398.

Callon, Michel. 1986. 'Some elements of a sociology of translation: domestication of the scallops and the fishermen of St Brieuc Bay.' In Power, Action and Belief: A New Sociology of Knowledge, edited by John Law, 196223. London and New York: Routledge.

- - - 2007. 'What does it mean to say that economics is performative?' In Do Economists Make Markets? On the Performativity of Economics, edited by D MacKenzie, F. Muniesa and L. Siu, 311-357. Princeton, N.J.: Princeton University Press.

Callon, Michel and John Law. 1997. 'After the individual in society: lessons on collectivity from science, technology and society.' Journal of Sociology 22 (2): 165-182.

Callon, Michel, Yuval Millo, and Fabian Muniesa. 2007. Market Devices.

Oxford: Blackwell Publishing.

Campbell, J.L. 1993. 'The state and fiscal sociology.' Annual Review of Sociology 19: 163-185.

Daun, Åke. 1989. Svensk mentalitet: Ett jämförande perspektiv. Stockholm: Nordstedts akademiska förlag.

Ehn, B. 1983. Ska vi leka tiger? Daghemsliv ur kulturell synvinkel. Lund: Liber Förlag. 
Ekonomistyrningsverket. 2012. 'Medborgares syn på myndigheter'. Stockholm: Ekonomistyrningsverket.

Garsten, C. 2008. '2. The United Nations - soft and hard: regulating social accountability for global business.' Organizing Transnational Accountability, 27-45. Cheltenham, UK: Edward Elgar.

Gusterson, Hugh. 1997. 'Studying up revisited.' PoLAR Political and Legal Anthropology Review 20 (1): 114-119.

Hannerz, Ulf. 2001. 'Introduktion: när fältet blir translokalt.' In Flera fält i ett. Socialantropologer om translokala fältstudier, edited by U. Hannerz, 7-35. Stockholm: Carlssons.

- — . 2006. 'Studying down, up, sideways, through, backwards, forwards, away and at home: reflections on the field worries of an expansive discipline.' In Locating the Field: Space, Place and Context in Anthropology, edited by Simon M Coleman \& Peter J Collins, 23-42. Oxford: Berg Publishers.

———. 2011. Café du Monde: Platser, vägar och människor i världsvimlet. Stockholm: Carlsson.

Holmes, Douglas R. 2009. 'Economy of words.' Cultural Anthropology 24 (3): 381-419.

Holmes, Douglas R., and George E. Marcus. 2005. 'Cultures of expertise and the management of globalization: toward the re-functioning of ethnography.' In Global Assemblages, 235-252.

- - - 2006. 'Para-ethnography and the rise of the symbolic analyst.' In Frontiers of Capital: Ethnographic Reflections on the New Economy, edited by M S Fisher and G Downey, 33-57. Durham: Duke University Press Books.

-_- 2008. 'Collaboration today and the re-imagination of the classic scene of fieldwork encounter.' Collaborative Anthropologies 1 (1): 81-101.

- — . 2012. 'Collaborative imperatives: a manifesto, of sorts, for the reimagination of the classic scene of fieldwork encounter.' In Collaborators Collaborating: Counterparts in Anthropological Knowledge and International Research Relations, edited by Monica Konrad, 126-143. Oxford: Berghahn Books.

Keohane, Robert O., and Joseph S. Jr. Nye. 1998. 'Power and interdependence in the information age.' Foreign Affairs 77 (5): 81-94.

Latour, Bruno. 1987. Science in Action. How to Follow Scientists and Engineers through Society. Science in Action. Cambridge, MA: Harvard University Press.

- - - 2010. The Making of Law: An Ethnography of the Conseil d'État. Cambridge: Polity.

Lodin, S 0. 2007. 'Några kvalitetskrav på en god skattelagstiftning.'

Skattenytt 2007 (9): 477-490. 
MacKenzie, Donald A. 2009. Material Markets: How Economic Agents Are Constructed. Oxford and New York: Oxford University Press.

Marques, R. 2004. 'Fiscal sociology: setting a research agenda.' Paper Presented at the American Sociological Association. San Fransisco.

Martin, Isaac William, Ajay K. Mehrotra, and Monica Prasad. 2009. The New Fiscal Sociology: Taxation in Comparative and Historical Perspective. Cambridge: Cambridge University Press.

Maurer, Bill, and Scott D Mainwaring. 2012. 'Anthropology with business : plural programs and future financial worlds.' Journal of Business Anthropology 1 (2): 177-196.

Murphy, Keith M. 2013. 'A cultural geometry: designing political things in Sweden.' American Ethnologist 40 (1): 118-131.

Nordblom, K. 2008. 'Svenska skatters legitimitet i en tid av globalisering. Rapport till Globaliseringsrådets skattegrupp'. Göteborg.

Nyqvist, Anette. 2008. Opening the Orange Envelope: Reform and Responsibility in the Remaking of the Swedish National Pension System. Stockholm: Department of Social Anthropology, Stockholm University.

Poon, Martha A. 2008. 'From New Deal institutions to capital markets: commercial consumer risk scores and the making of subprime mortgage finance.' Accounting, Organizations and Society 34 (5): 654-74.

Riles, Annelise. 2006. Documents : Artifacts of Modern Knowledge. Ann Arbor: University of Michigan Press.

——_. 2010. 'Collateral expertise.' Current Anthropology 51 (6): 795-818.

Roitman, Janet L. 2005. Fiscal Disobedience: An Anthropology of Economic Regulation in Central Africa. Princeton : Princeton University Press.

Rosenberg, G. 2002. 'The crisis of consensus in postwar Sweden.' In Culture and Crisis. The Case of Germany and Sweden, edited by Nina Witoszek and Lars Trägårdh, 170-201. New York: Berghahn.

Skatteverket. 2005. 'Riskvärdering'. Vol. 8. Stockholm: Skatteverket.

———. 2006. 'Svartköp och svartjobb i Sverige. Del 1:

Undersökningsresultat.' Stockholm: Skatteverket.

___. 2007. 'Medborgarnas synpunkter på skattesystemet, skattefusket och Skatteverkets kontroll'. Vol. 3. Stockholm.

———. 2011. 'Skatteverkets inriktning'. Vol. 118. Stockholm.

Thedvall, Renita. 2006. Eurocrats at Work: Negotiating Transparency in Postnational Employment Policy. Stockholm: Department of Social Anthropology, Stockholm University.

Valverde, Mariana. 2003. Law's Dream of a Common Knowledge. Princeton, N.J.: Princeton University Press. 
Valverde, Mariana, Ron Levi, and Dawn Moore. 2005. 'Legal knowledges of risks.' In Law Risk, edited by The Law Commission Of Canada, 86-120. Vancouver: University of British Columbia Press.

Zaloom, C. 2006. Out of the Pits: Traders and Technology from Chicago to London. University of Chicago Press.

Lotta Björklund Larsen holds a post-doctoral position at the institution for Thematic Studies - Technology and Social Change - at Linköping University, Sweden. Her research concerns how exchanges are considered economic, and how the boundary to the non-economic is defined and maintained at the interface between individuals' values, governmental regulations and institutional impact. This article is part of her current project 'Swedish tax dynamics. Values and practices at the Swedish tax agency and the economization of society', funded by Riksbankens Jubileumsfond. She has recently published in Focaal and the Journal of Cultural Economy. 